\title{
Distribution and Speciation of Heavy Metals in Water and Sediments of the Coastal Marine Areas of Tanzania
}

\author{
Sharifa Omar Bungala*, John Machiwa, Daniel Shilla \\ Department of Aquatic Sciences and Fisheries, University of Dar es Salaam, Dar es Salaam, Tanzania \\ Email: *sharifa.bungala@pccb.go.tz
}

How to cite this paper: Bungala, S.O., Machiwa, J. and Shilla, D. (2021) Distribution and Speciation of Heavy Metals in Water and Sediments of the Coastal Marine Areas of Tanzania. Journal of Environmental Protection, 12, 734-754.

https://doi.org/10.4236/jep.2021.1210044

Received: January 3, 2020

Accepted: October 18, 2021

Published: October 21, 2021

Copyright $\odot 2021$ by author(s) and Scientific Research Publishing Inc. This work is licensed under the Creative Commons Attribution International License (CC BY 4.0).

http://creativecommons.org/licenses/by/4.0/

\begin{abstract}
The present study investigated the concentration and species of heavy metals $\mathrm{As}, \mathrm{Hg}, \mathrm{Cr}, \mathrm{Pb}$ and $\mathrm{Zn}$ in water and $\mathrm{As}, \mathrm{Hg}, \mathrm{Cr}, \mathrm{Pb}$ and $\mathrm{Zn}$ in sediments collected along the coastal marine areas of Tanzania so as to determine their behaviour and remobilization potential in the environment and the degree of their availability to edible aquatic biota for monitoring purposes. Sequential extraction revealed the presence of a significant proportion of heavy metals $\mathrm{Cr}, \mathrm{Pb}$ and $\mathrm{Zn}$ bound to available fractions of sediments. Arsenic had the highest concentration in non available residual fractions. PCA analysis found that $\mathrm{As}-\mathrm{Hg}, \mathrm{Cr}-\mathrm{Pb}$ were strongly correlated and that the two may be derived from the same source most likely from storm water drainage of waste water discharges, while $\mathrm{Zn}$ may have come from the different source like watershed erosion. Further, PCA clearly confirms the same. Generally, $\mathrm{Zn}$ among all heavy metals analysed was the most available to aquatic biota due to its higher average concentrations in the acid soluble fraction, followed by chromium. However, high percentages of metal species studied in Tanzania coastal marine areas were found in non available fractions which indicated that the edible aquatic biota was safe for human consumptions.
\end{abstract}

\section{Keywords}

Heavy Metals, Sediment, Sequential Extraction, Speciation, Bioavailable

\section{Introduction}

Different physico-chemical forms (species) of an element can co-exist and may or may not be in thermodynamic equilibrium with one another [1]. Knowledge of the chemical forms of elements is essential for estimating their biological availability, physico-chemical reactivity and elemental transport in the environment 
and into the food chain. Variation in the speciation of heavy metals will also affect their degree of adsorption on suspended matter, their rate of transfer to the sediments and their overall transport in a water system [1]. For example, inorganic arsenic in seawater is biotransformed into organoarsenic compounds by marine biota and more than 20 organoarsenic compounds have been identified [2]. The oxidation state of an element also plays an important role on bioavailability and toxicity. For example, among the two chromium oxidation states, $\mathrm{Cr}$ (III) is considered one of the essential elements for living organisms, whereas $\mathrm{Cr}$ (VI) is toxic to biota and has been reported as carcinogenic. On the other hand, As (III) is much more toxic than As (V) [3].

Speciation is not only very useful for determining the degree of association of the metals in the sediments and to what extent they may be remobilized into the environment [3], but also for distinguishing those metals with a lithogenic origin which are usually not-available to aquatic biota, from those with an anthropogenic origin which usually are available to aquatic biota. The level of bioavailability of a specific metal depends on the fraction of sediment to which it is adsorbed, e.g. metals bound to water-soluble or carbonate molecules (exchangeable fraction), Fe and Mn oxides and hydroxides (reducible fraction), organic matter and sulphides (oxidisable fraction). Metals bound to exchangeable fractions are resuspended readily, whereas reducible and oxidisable fractions require biological or chemical processes to occur before they are made bioavailable [4]. Speciation studies also help to understand the extent of enrichment of metals in the environment by calculation of an enrichment factor (EF). According to [5], EF is defined as the ratio between the total metal concentration and the metal concentration in the residual phase. The enrichment factor indicates how much the sediment is enriched relative to metal concentration in the residual fraction which is mainly of lithogenic origin. EF values that are equal to one suggest no enrichment, and those which are substantially greater than one (more than two) suggest anthropogenic input of metals.

$$
\mathrm{EF}=([\mathrm{MeF} 1])+[\mathrm{MeF} 2]+[\mathrm{MeF} 3]+\frac{[\mathrm{MeF} 4]}{[\mathrm{MeF} 4]}
$$

where, Me is the concentration of a metal in the sequential extraction fractions $\left(\mathrm{F}_{1}, \mathrm{~F}_{2}, \mathrm{~F}_{3}, \mathrm{~F}_{4}\right)$.

Several methods for determining the different forms of metals in sediments have been described in the scientific literature [6]. The most widely used methods are based on sequential extraction procedures whereby several reagents are used consecutively to extract operationally defined phases from a sediment sample in a sequence [7]. Generally, for sediment samples a combination of operationally defined physical and chemical separation techniques are utilised in the measurement of the kinetically labile or bioavailable metals including the free hydrated metal and inorganic complexes, organically bound complexes and total metal complexes. The aim of this study was to investigate speciation of the metals $\mathrm{As}, \mathrm{Hg}, \mathrm{Cr}, \mathrm{Pb}$ and $\mathrm{Zn}$ in water and sediments so as to determine their 
behaviour and remobilization potential in the environment and the degree of their availability to aquatic biota for monitoring purposes, so as to make sure edible aquatic biota remained to be safe for human consumptions.

\section{Materials and Methods}

\subsection{Study Area}

This study was executed in the coastal waters of Tanzania in the western Indian Ocean. The coastal area of Tanzania (Figure 1) encompasses a number of habitats that include coral reefs, mangroves, seagrass beds, sand banks, wetlands and beaches which support various resources both living and nonliving, and provides life support to coastal communities where such activities as fisheries and related activities play an important role in the social and economic development of local communities. The coastal areas (Dar es Salaam, Tanga, Zanzibar and Mtwara) are faced with expanding populations and emerging land-based activities such as agriculture, mineral exploitation and industrial activities which exert pressures on coastal waters, thus negatively affecting water quality. It receives water from both rivers as well as large amounts of domestic and industrial effluents. The studied area are also characterised by local harbour activities while at Dar es Salaam port area, Mtwara port area and Tanga port area, there are harbour and ship fumigation activities and also loading and offloading of different types of cargo.

\subsection{Establishment of the Sampling Stations}

Eight sampling stations were located in the estuarine of rivers and three in marine areas near ports. Water, sediments and biota were collected from estuaries of these rivers: Pangani, Wami, Ruvu, Mzinga, Msimbazi, Rufiji, Matandu and Ruvuma (Figure 1). The port areas from which samples were collected were Dar es Salaam, Tanga and Mtwara (Figure 1). The positions of sampling stations were determined using a Geographical Positioning System (Garmin GPS 72), as shown in Table 1. Three sites were established which are NCMAs (Northern Coastal Marine Areas) (stations 1, 2, 3 and 4), CCMAs (Central Coastal Marine Areas) (stations 5, 6 and 7) and SCMAs (Southern Coastal Marine Areas) (stations $8,9,10$ and 11$)$.

\subsection{Sample Collection and Measurements of Physico-Chemical Parameters}

All the plastic and glassware used for metals analysis were washed with detergent, soaked in 5\% nitric acid overnight, rinsed at least three times with de-ionized water and dried at air temperature in the hood before use. All reagents for treatment of samples for heavy metals analyses were Suprapur or Ultrapure grade, supplied by Merck (Darmstadt, Germany) or Sigma-Aldrich (Steinhein, Germany). All solutions were prepared using deionised water. Sampling was conducted after the rainy season between June and July 2011. Prior to the water 


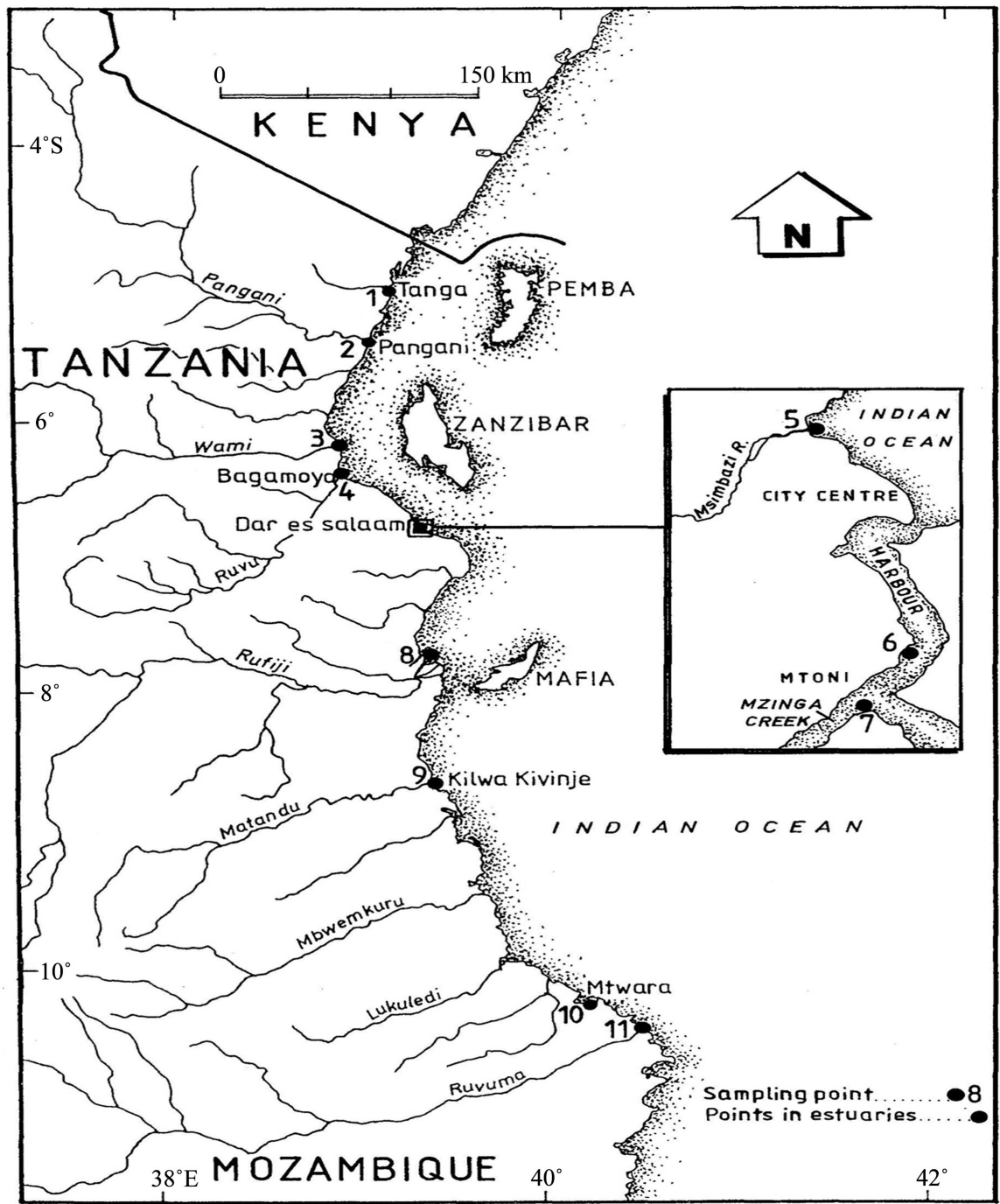

Figure 1. Map of the marine coast of Tanzania showing the eleven sampling stations.

Table 1. Sampling locations in estuaries and port areas along the coastal marine areas of tanzania.

\begin{tabular}{cccc}
\hline Site & Location & Station & Coordinates \\
\hline & Tanga Port Area (TPA) & 1 & $5^{\circ} 1.43^{\prime} \mathrm{S} ; 39^{\circ} 5.16^{\prime} \mathrm{E}$ \\
$\begin{array}{c}\text { NCMA (Northern Coastal } \\
\text { Marine Areas) }\end{array}$ & $\begin{array}{c}\text { Pangani River Estuary (PRE) } \\
\text { Wami River Estuary (WRE) }\end{array}$ & 2 & $5^{\circ} 25.46^{\prime} \mathrm{S} ; 38^{\circ} 58.01^{\prime} \mathrm{E}$ \\
& Ruvu River Estuary (RRE) & 4 & $6^{\circ} 7.17^{\prime} \mathrm{S} ; 38^{\circ} 48.53^{\prime} \mathrm{E}$ \\
& Msimbazi River Estuary (MRE) & 5 & $6^{\circ} 47.50^{\prime} \mathrm{S}$ ' $; 38^{\circ} 52.09^{\circ} 16.54^{\prime} \mathrm{E}$ \\
\hline $\begin{array}{c}\text { CCMA (Central Coastal } \\
\text { Marine Areas) }\end{array}$ & Dar es Salaam Port Area (DPA) & 6 & $6^{\circ} 51.32^{\prime} \mathrm{S} ; 39^{\circ} 17.49^{\prime} \mathrm{E}$ \\
& Mzinga Creek (MZC) & 7 & $6^{\circ} 52.19^{\prime} \mathrm{S} ; 39^{\circ} 17.21^{\prime} \mathrm{E}$ \\
\hline \multirow{2}{*}{$\begin{array}{c}\text { SCMA (Southern Coastal } \\
\text { Marine Areas) }\end{array}$} & Matandu River Estuary (MAE) & 9 & $8^{\circ} 43.26^{\prime} \mathrm{S} ; 39^{\circ} 21.41^{\prime} \mathrm{E}$ \\
& Mtwara Port Area (MPA), & 10 & $10^{\circ} 16.18^{\prime} \mathrm{S} ; 40^{\circ} 11.13^{\prime} \mathrm{E}$ \\
& Ruvuma River Estuary (RVE) & 11 & $10^{\circ} 29.35^{\prime} \mathrm{S} ; 40^{\circ} 24.58^{\prime} \mathrm{E}$ \\
\hline
\end{tabular}


and sediment sampling, the surface water temperature, $\mathrm{pH}$, salinity, conductivity and dissolved oxygen were measured in situ using a temperature-compensated Multi Parameter Analyser (Horiba U-10 water quality checker). Water and sediment samples were collected from eleven sampling stations along the coastal marine area of Tanzania (Figure 1).

Seawater samples were collected few centimeters below the surface into 1-litre acid washed polyethene bottles for heavy metals analysis. Triplicate samples were collected at each station and extra 5 litres were collected for suspended particulate matter analysis. The water samples were immediately stored on ice in a cooler and later stored frozen in the laboratory before analysis. Surface sediment samples were collected by a sediment corer and placed in pre-cleaned polyethylene bags and stored in a cooler box. Only sediment from the biologically-active surface layer (top $5 \mathrm{~cm}$ ) was collected and debris was removed. Each sample was sealed in a plastic bag, stored on ice in a cooler and then immediately transferred into a freezer in the laboratory for storage at $-18^{\circ} \mathrm{C}$. Thirty three samples were collected from the sampling stations for heavy metals analysis. Before analysis sediment samples were freeze dried, grounded sieved with a $63 \mu \mathrm{m}$ mesh sieve and stored in pre-cleaned plastic containers prior to digestion.

\subsection{Laboratory Sample Preparation and Analysis}

\subsubsection{Determination of Metals Speciation in Water}

Water (3 litres) samples were filtered through Whatman filter papers no. $4 \mathrm{im}$ mediately after reaching the laboratory and then stored at approximately $4^{\circ} \mathrm{C}$ in order to avoid changes in physical-chemical and biological properties. Before analysis filtered water samples were sub-sampled into two portions in order to measure the different metal species according to the fractionation scheme in Figure 2. One portion was digested with nitric acid and incubated (in a culture test tube in a water bath) at $80^{\circ} \mathrm{C}$ to give a solution with a $\mathrm{pH}$ of approximately 2 before analysis for total heavy metals. The other portion was filtered through $0.45 \mu \mathrm{m}$ membrane filter. The filtrate was analysed without digestion to obtain dissolved metals fraction. The first fraction contained thermodynamically reactive and non-reactive chemical species [8].

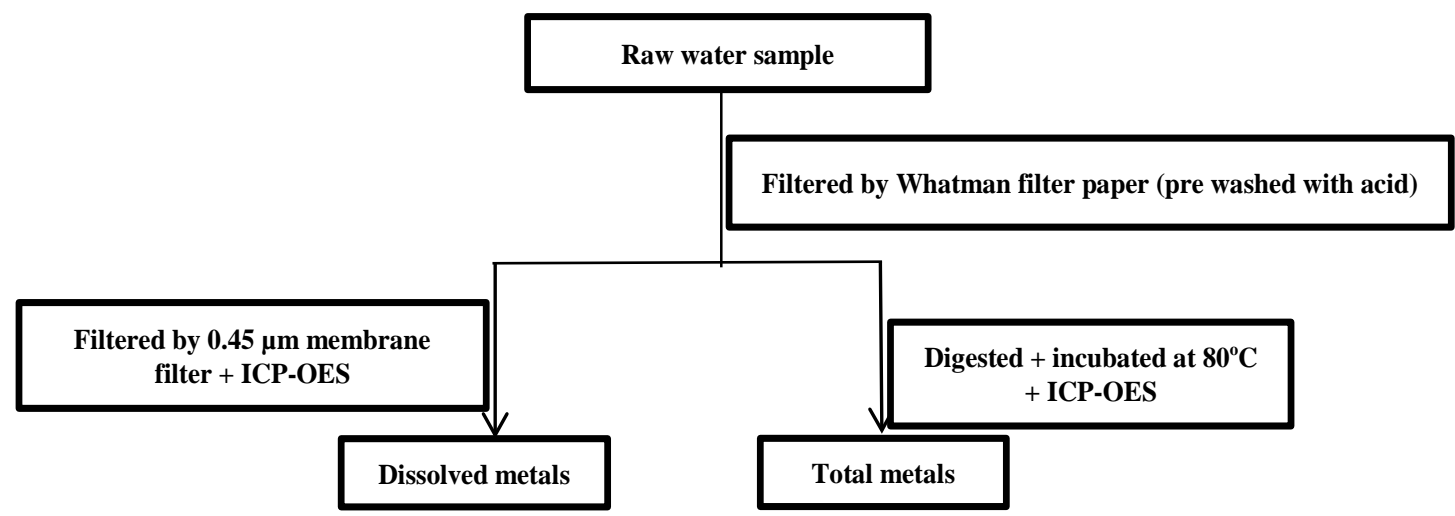

Figure 2. Metal speciation scheme for water samples (Schwarz, 1977). 
In all cases, blanks using ultrapure water (Milli-Q) were treated similar to the samples. Sample handling and preparation of solutions were carried out wearing polyethylene gloves. Arsenic, mercury, lead, chromium and zinc concentrations were analysed by Inductively Coupled Plasma-Optical Emission Spectrometry (ICP-OES), ULTIMA 2 Horiba at SEAMIC laboratories Dar es Salaam. Mercury was analyzed by hydride generation technique (HG-ICPOES) and other elements by direct aspiration after dilution.

In inductively coupled optical emission spectroscopy (ICP-OES), a sample solution (for measurement of As, $\mathrm{Cr}, \mathrm{Pd}$ and $\mathrm{Zn}$ ) is introduced into the core of inductively coupled argon plasma (using a high-accuracy nebulizer by free aspiration and a gravity drain), which generates temperatures of approximately $8000^{\circ} \mathrm{C}$. At this temperature, all elements become thermally excited and emit light at their characteristic wavelengths. This light is collected by the spectrometer and passes through a diffraction grating that serves to resolve the light into a spectrum of its constituent wavelengths. Within the spectrometer, this diffracted light is then collected by wavelength and amplified to yield an intensity measurement that can be converted to an elemental concentration by comparison with calibration standards. Operating conditions of the ICP-OES are described in Table 2.

All measurements were performed using a $20 / 15 \mu \mathrm{m}$ slit combination with integration time ranging from 3 to 10 seconds according to the element.

Mercury ( $\mathrm{Hg}$ ) determination in samples was performed with a Flow Injection Hydride Generation System FIAS 400 with Inductively Coupled Plasma Optical Emission Spectrometer ICP-OES type ULTIMA 2 Horiba. For the hydride vapour generation two types of solutions were used: $3 \%(\mathrm{v} / \mathrm{v}) \mathrm{HCl}$ as carrier solution, and $0.3 \% \mathrm{NaBH} 4(\mathrm{w} / \mathrm{v})$ in $0.5 \% \mathrm{NaOH}(\mathrm{w} / \mathrm{v})$ solution (freshly prepared) as reducing agent (as according to the procedure described in Romanian Standard SR EN ISO 11885/2009) [9]. This method has a detection limit of $\mathrm{Hg} 0.1 \mu \mathrm{g} \mathrm{L}-1$, situated under the limit values imposed by legislation. Plasma generation of the ICP-OES spectrometer requires argon gas as fuel and therefore nitrogen gas was used only for the cooling system of the equipment. The purity of all reagents used is critical when determining low levels of hydride elements. The operational parameters for FIAS-ICP-OES method and data processing are presented in Table 3.

Table 2. Operating conditions of the ICP-OES:

\begin{tabular}{cc}
\hline Parameters & Specification \\
\hline RF Generator Power & $1200 \mathrm{~W}$ \\
Plasma gas & $14 \mathrm{~L} / \mathrm{min}$ \\
Auxiliary gas & $0.8 \mathrm{~L} / \mathrm{min}$ \\
Sheath gas & $0.3 \mathrm{~L} / \mathrm{min}$ \\
Nebulizer flow & $0.8 \mathrm{~L} / \mathrm{min}$ \\
\hline
\end{tabular}


Table 3. Optimization parameters for $\mathrm{Hg}$ detection by FIAS-ICP-OES.

\begin{tabular}{|c|c|c|c|c|c|}
\hline \multicolumn{6}{|c|}{ Spectrometer Parameters } \\
\hline \multicolumn{3}{|c|}{ Hg Wavelength: $194.168 \mathrm{~nm}$} & \multicolumn{3}{|c|}{ Replicates 3 times } \\
\hline \multicolumn{3}{|c|}{ Integration time: $0.05 \mathrm{~s}$} & \multicolumn{3}{|c|}{ Transient Read Delay $0.0 \mathrm{~s}$} \\
\hline \multicolumn{6}{|c|}{ Plasma parameters } \\
\hline \multicolumn{3}{|c|}{ Plasma flow rate $15 \mathrm{~L} / \mathrm{min}$} & \multicolumn{3}{|c|}{ Power RF 1300 W } \\
\hline \multicolumn{3}{|c|}{ Auxiliary flow rate $0.2 \mathrm{~L} / \mathrm{min}$} & \multicolumn{3}{|c|}{ Plasma view Axial } \\
\hline \multicolumn{3}{|c|}{ Nebulizer flow rate $0.6 \mathrm{~L} / \mathrm{min}$} & \multicolumn{3}{|c|}{ View distance $15.0 \mathrm{~mm}$} \\
\hline \multicolumn{6}{|c|}{ Flow Injection Programme } \\
\hline Step & Time (s) & Pump 1 (U/min) & Pump $2(\mathrm{U} / \mathrm{min})$ & Valve & Read \\
\hline Prefil & 15 & 80 & 100 & Fill & - \\
\hline 1 & 10 & 80 & 100 & Fill & - \\
\hline 2 & 15 & 80 & 100 & Inject & On \\
\hline \multicolumn{3}{|c|}{ Spectral Peak Processing } & \multicolumn{3}{|c|}{ Time Processing } \\
\hline \multicolumn{3}{|c|}{ Peak Algorithm: Peak Height } & \multicolumn{3}{|c|}{ Peak Algorithm: Peak Height } \\
\hline \multicolumn{3}{|c|}{ Points per peak: 3 points } & \multicolumn{3}{|c|}{ Smooting points: 19 points } \\
\hline \multicolumn{3}{|c|}{ Spectral corrections: None } & & & \\
\hline
\end{tabular}

$\mathrm{Hg}$ was detected at specific wavelength $(194.168 \mathrm{~nm})$ and the method applied with the used equipment was perfectly able to measure it accurately even in presence of interferents.

\subsubsection{Determination of Sediment Characteristics and Metal Contents}

Total Organic Matter (TOM) was measured by the loss-on-ignition (LOI) method for the determination of organic matter. Approximately $2 \mathrm{~g}$ of sediment sample was placed in a ceramic crucible which was then ignited at $500^{\circ} \mathrm{C}$ overnight in order to destroy organic matter [10]. The sample was then cooled in a desiccator and weighed. Organic matter content was calculated as follows:

$$
\operatorname{TOM}(\%)=\frac{W_{i}-W_{f}}{W_{i}} \times 100
$$

where $W_{i}$ is the initial weight of a sample before burning and $W_{f}$ is the final weight of sample after burning. All weights were corrected for moisture/water content prior to organic matter content calculations.

Sediment grain size distribution was determined on freeze-dried sediments by using a shaker and stainless steel sieves. The percentage amount of each grain size was calculated using the initial weight of the sample and the separate weights of each grain size. The particle size distribution in the sediment was analysed in the Department of Aquatic Sciences and Fisheries, University of Dar es Salaam.

The total metal concentration was determined after digestion of sediment samples at $180^{\circ} \mathrm{C}$ on a sand bath heater using a mixture of $2 \mathrm{ml} \mathrm{HNO}_{3}, 2 \mathrm{ml}$ $\mathrm{H}_{2} \mathrm{O}_{2}$ and $0.5 \mathrm{ml} \mathrm{HF}$ [11] in PTFE beakers. The supernatant solution was filtered using (Whatman cellulose acetate $0.45 \mu \mathrm{m}$ ), diluted to $25 \mathrm{ml}$ and stored at $4^{\circ} \mathrm{C}$ 
prior to analysis. A blank was prepared without the addition of sediment. Certified reference material, Stream sediment (STSD-1) from the Canadian Certified Reference Materials Project (CCRMP), produced by CANMET Mining and Minerals Sciences Laboratories, was digested along with the samples to provide an indication of the extraction efficiency of the method.

In order to quantify the proportion of metal species that might be available to living organisms, the speciation of metals in sediments was established according to the procedure by [11] as modified from Community Bureau of Reference - BCR [7]. The BCR's three-step sequential extraction procedure was used to obtain metal fractions in the non-residual sediment phases (available fractions). The residual phase of the sediment matrix was extracted by introducing a fourth step [11], as explained below and shown schematically in Figure 3.

After every step of extraction, the residue was washed with $20 \mathrm{ml}$ of Milli-Q water by shaking for $15 \mathrm{~min}$ and centrifuging for $20 \mathrm{~min}$. The liquid was discarded and the sediment residue retained for the second stage of extraction. The collected supernatant was filtered (Whatman cellulose acetate $0.45 \mu \mathrm{m}$ ) and stored at $4^{\circ} \mathrm{C}$ prior to analysis. A blank was prepared without the addition of sediment. The analysis of the digest solutions of sediment for $\mathrm{As}, \mathrm{Hg}, \mathrm{Cr}, \mathrm{Pb}$ and $\mathrm{Zn}$ was performed by ICP-OES. Mercury was analyzed by hydride generation technique (HG-ICP OES) and other elements by direct aspiration after dilution. Analytical blanks were run in the similar way as that of the samples. Metal concentrations were determined using standard solutions prepared in the same acid matrix.

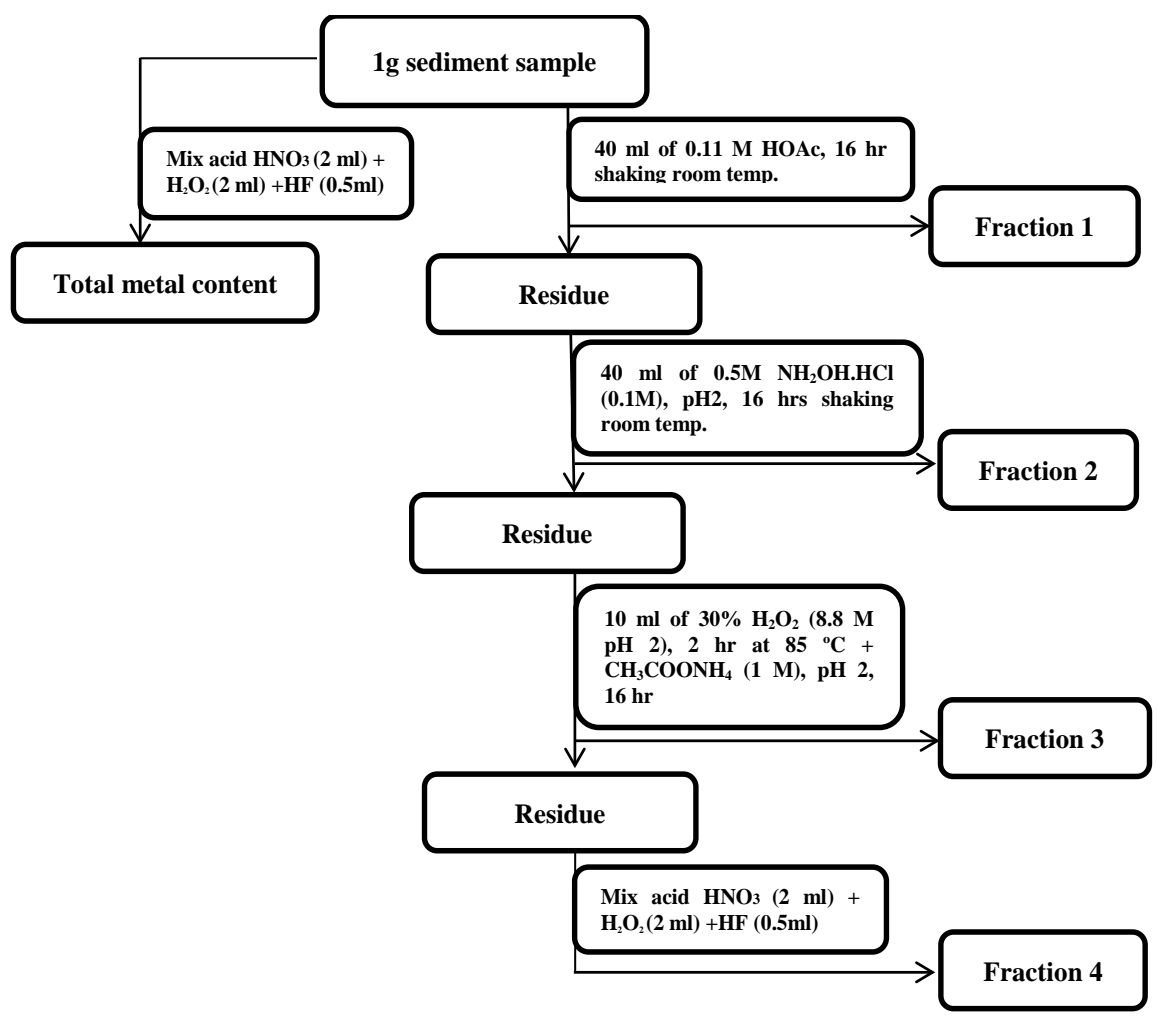

Figure 3. Sequential Extraction of Metals in Sediment Samples (adapted from Yuan et al., 2004). 


\subsection{Quality Control: Extraction Efficiency of the Analytical Protocol}

The certified reference material was included with the samples to provide an indication of the extraction efficiency of the method. STSD-1 (Stream sediment reference materials) produced specifically by the Canadian Certified Reference Materials Project (CCRMP), CANMET Mining and Minerals Sciences Laboratories, for use in the BCR sequential extraction procedure. Table 4 shows the extraction efficiency of the analytical protocol used for the digestion of sediment samples for total metal analysis. The comparison of the experimental results with the certified values indicates that the recovery of metal species from the sediment was between $87 \%$ and $106 \%$ which is an acceptable range.

\subsection{Statistical Analysis}

Statistical analyses were performed using SPSS 16.0 for Windows, Microsoft excel and PRIMER 6. Results of the metal analyses were subjected to a one-way Analysis of variance (ANOVA) by SPSS to test for significant differences ( $\mathrm{p}=$ 0.05 ) in the concentrations of metals in water and sediments at the different sampling sites. Correlation analysis was applied for total organic matter and grain size with total metals in sediments between sites. Principal Component Analysis (PCA) was applied to identify the distribution patterns and sources of metals in the study area. The significance level was set at 0.05 .

\section{Results}

\subsection{Water and Sediment Characteristics}

The physico-chemical characteristics of water samples from the estuarine and port sampling stations were generally similar with the exception of $\mathrm{pH}$ and salinity. The sea water from the SCMA had comparatively highest $\mathrm{pH}$ (9.8) followed by CCMA (9.2) and the NCMA had an average $\mathrm{pH}$ of (7.9). On the other hand, CCMA had highest salinity (33.8\%), followed by NCMA (27.7\%o) and the SCMA (21.6\%). Generally, the Ruvuma River Estuary station had the lowest $\mathrm{pH}$ $(7.1 \pm 2.2)$, while the highest $\mathrm{pH}(10.9 \pm 3.1)$ was recorded near Mtwara Port Area in the SCMA (Table 5). Similarly, salinity was lowest (14.3\%o $\pm 1.2 \%$ ) at Rufiji River Estuary within SCMA and was highest at the Dar es Salaam Port Area in CCMA $(38 \% \pm \pm 6.5 \%)$.

The grain size distribution in the sediments from the coastal marine areas of Tanzania (Table 6) indicates that sediments from NCMA had higher clay/silt content (43\%) compared to the CCMA (36\%) and SCMA (32\%) sites. The highest Clay/Silt content $(52 \% \pm 10.1 \%)$ was recorded in sediment samples from Ruvu River Estuary and the lowest amount $(25 \% \pm 4.1 \%)$ was present in sediment sample from Rufiji River Estuary (Table 6). The total organic matter content in sediments samples was highest $(6.6 \% \pm 1.5 \%)$ in Ruvuma River estuary and lowest $(3.7 \% \pm 0.1 \%)$ in the sediments from Matandu River Estuary (Table $6)$. 
Table 4. Comparison between the experimental results for sediment extraction of total metals concentration ( $\mu \mathrm{g} / \mathrm{g}$ dry weight) with the certified values for the reference material $\left(\mathrm{STSD}-1^{*}\right)$.

\begin{tabular}{cccccc}
\hline & As & $\mathrm{Hg}$ & $\mathrm{Cr}$ & $\mathrm{Pb}$ & $\mathrm{Zn}$ \\
\hline Experimental & 1.5 & 0.54 & 26.5 & 26 & 167.2 \\
Certified & 1.7 & 0.51 & 28 & 30 & 165 \\
\% Recovery & $88 \%$ & $106 \%$ & $95 \%$ & $87 \%$ & $101 \%$
\end{tabular}

* STSD - $1=$ Standard Deviation -1.

Table 5. Wavelength $(\mathrm{nm})$, view \& detection limits for elements $\mathrm{As}, \mathrm{Cr}, \mathrm{Pb}$ and $\mathrm{Zn}$ in ICP-OES.

\begin{tabular}{ccccc}
\hline Element & Wavelength $(\mathrm{nm})$ & View & $\begin{array}{c}\text { Instrument Detection } \\
\text { Limit } \mu \mathrm{g} \cdot \mathrm{Kg}^{-1}\end{array}$ & $\begin{array}{c}\text { Method Detection } \\
\text { Limit } \mu \mathrm{g} \cdot \mathrm{Kg}^{-1}\end{array}$ \\
\hline $\mathrm{As}$ & 189.042 & Axial & 1.7 & 85 \\
$\mathrm{Cr}$ & 267.716 & Axial & 0.7 & 35 \\
$\mathrm{~Pb}$ & 220.353 & Axial & 2.0 & 1000 \\
$\mathrm{Zn}$ & 206.200 & Axial & 0.2 & 0 \\
\hline
\end{tabular}

Table 6. Physico-chemical characteristics of water and sediment organic matter and Clay/ Silt content at the sampling stations.

\begin{tabular}{cccccccc}
\hline Location & Station & Temp. $\left({ }^{\circ} \mathrm{C}\right)$ & $\mathrm{pH}$ & Salinity $(\%)$ & $\mathrm{DO} \mathrm{mg} / \mathrm{l}$ & $\mathrm{TOM}(\%)$ & Clay/silt \% \\
\hline & 1 & $27.0 \pm 3.2$ & $7.8 \pm 0.3$ & $33.3 \pm 5.1$ & $6.1 \pm 0.3$ & $5.0 \pm 0.3$ & $47.0 \pm 8.5$ \\
\multirow{2}{*}{ NCMA } & 2 & $27.0 \pm 4.2$ & $8.0 \pm 0.3$ & $24.6 \pm 3.2$ & $4.5 \pm 0.1$ & $5.1 \pm 0.2$ & $38.0 \pm 5.2$ \\
& 3 & $27.0 \pm 2.1$ & $7.4 \pm 0.1$ & $21.0 \pm 2.1$ & $6.2 \pm 0.4$ & $4.3 \pm 0.2$ & $35.0 \pm 6.3$ \\
& 4 & $28.0 \pm 4.1$ & $8.5 \pm 0.4$ & $32.0 \pm 4.1$ & $6.4 \pm 0.2$ & $6.4 \pm 1.1$ & $52.0 \pm 10.1$ \\
\hline \multirow{2}{*}{ CCMA } & 5 & $28.0 \pm 3.2$ & $8.5 \pm 0.2$ & $32.0 \pm 4.5$ & $5.6 \pm 0.2$ & $4.9 \pm 0.3$ & $40.0 \pm 1.1$ \\
& 7 & $27.0 \pm 3.1$ & $8.8 \pm 0.2$ & $38.0 \pm 6.5$ & $6.0 \pm 0.2$ & $5.6 \pm 0.1$ & $36.0 \pm 7.3$ \\
& 8 & $27.0 \pm 3.3$ & $10.5 \pm 0.3$ & $14.3 \pm 1.2$ & $6.5 \pm 0.5$ & $5.6 \pm 0.2$ & $25.0 \pm 4.1$ \\
& 9 & $26.0 \pm 2.4$ & $10.8 \pm 0.2$ & $27.4 \pm 2.3$ & $5.3 \pm 0.2$ & $3.7 \pm 0.1$ & $41.0 \pm 9.1$ \\
SCMA & 10 & $30.0 \pm 5.1$ & $10.9 \pm 0.4$ & $27.5 \pm 2.5$ & $5.1 \pm 0.3$ & $5.0 \pm 0.3$ & $29.0 \pm 1.5$ \\
& 11 & $29.0 \pm 4.2$ & $7.1 \pm 0.2$ & $17.0 \pm 1.5$ & $6.1 \pm 0.4$ & $6.6 \pm 1.5$ & $35.0 \pm 5.1$ \\
\hline
\end{tabular}

\subsection{Metal Concentration in Water}

\subsubsection{Mercury}

Concentration of total $\mathrm{Hg}$ in the coastal marine areas of Tanzania was below the recommended value of $0.30 \mu \mathrm{g} / \mathrm{l}$ when compared to the maximum concentration water quality guideline value by UNEP [12] (Table 7).

Dissolved mercury concentration ranged from 0.10 to $0.30 \mathrm{ng} / \mathrm{l}$ while particulate mercury ranged from 0.10 to $0.40 \mathrm{ng} / \mathrm{l}$. When comparing individual stations, 
Pangani River Estuary (station 2), Wami River Estuary (station 3), Msimbazi River Estuary (station 5) and Dar es Salaam Port Area (station 6) were the only stations which had dissolved $\mathrm{Hg}$ concentration greater than $0.10 \pm 0.04 \mathrm{ng} / \mathrm{l}$ (Table 7). Comparing sampling stations, concentration of particulate $\mathrm{Hg}$ was highest $(0.32 \pm 0.01 \mathrm{ng} / \mathrm{l})$ in Msimbazi River Estuary (station 5) and the lowest concentration (below detection limits) was in the water samples from Tanga Port Area, Ruvu River Estuary, Rufiji River Estuary, Mtwara Port Area and Ruvuma River Estuary (Table 7).

\subsubsection{Chromium}

Total $\mathrm{Cr}$ concentration in water samples was below the recommended value of $10.0 \mu \mathrm{g} / \mathrm{l}$., in comparison with the maximum concentration water quality guideline value by UNEP [12].

The dissolved chromium in water samples was detected only at Wami River Estuary $(0.01 \pm 0.00 \mu \mathrm{g} / \mathrm{l})$, while particulate chromium was detected in water samples from all stations, ranging from 0.02 to $0.06 \mu \mathrm{g} / \mathrm{l}$ (Table 7). The concentration of particulate $\mathrm{Cr}$ was higher $(0.06 \pm 0.02 \mu \mathrm{g} / \mathrm{l})$ at Mzinga Creek and Mtwara Port Area while the lowest concentration $(0.02 \pm 0.01 \mu \mathrm{g} / \mathrm{l})$ was found in the water samples from Wami River Estuary and Ruvu River Estuary (Table 7).

\subsubsection{Zinc}

Concentration of total $\mathrm{Zn}$ in water samples was below the recommended value of $17.0 \mu \mathrm{g} / \mathrm{l}$, in comparison with the maximum concentration water quality guideline value by UNEP [12].

Table 7. Total, dissolved and particulate metals concentrations $( \pm \mathrm{SD})$ and UNEP EQT $(\mu \mathrm{g} / \mathrm{l})$ in coastal marine waters of tanzania.

\begin{tabular}{|c|c|c|c|c|c|c|c|c|c|}
\hline Stations & $\begin{array}{l}\text { Total Hg } \\
\text { (ng/l) }\end{array}$ & $\begin{array}{l}\text { Dissol. Hg } \\
\text { (ng/l) }\end{array}$ & $\begin{array}{l}\text { Partic. Hg } \\
\text { (ng/l) }\end{array}$ & $\begin{array}{c}\text { Total Cr } \\
(\mu \mathrm{g} / \mathrm{l})\end{array}$ & $\begin{array}{l}\text { Dissol. Cr } \\
(\mu \mathrm{g} / \mathrm{l})\end{array}$ & $\begin{array}{l}\text { Partic. Cr } \\
\quad(\mu \mathrm{g} / \mathrm{l})\end{array}$ & $\begin{array}{l}\text { Total Zn } \\
(\mu \mathrm{g} / \mathrm{l})\end{array}$ & $\begin{array}{c}\text { Dissol. Zn } \\
(\mu \mathrm{g} / \mathrm{l})\end{array}$ & $\begin{array}{l}\text { Partic. Zn } \\
\quad(\mu \mathrm{g} / \mathrm{l})\end{array}$ \\
\hline 1 & $0.11 \pm 0.03$ & $0.11 \pm 0.03$ & n.d. & $0.06 \pm 0.03$ & n.d. & $0.06 \pm 0.03$ & $0.10 \pm 0.04$ & $0.03 \pm 0.02$ & $0.07 \pm 0.02$ \\
\hline 2 & $0.30 \pm 0.06$ & $0.10 \pm 0.02$ & $0.20 \pm 0.04$ & $0.05 \pm 0.02$ & n.d. & $0.05 \pm 0.02$ & $0.19 \pm 0.06$ & $0.02 \pm 0.02$ & $0.17 \pm 0.04$ \\
\hline 3 & $0.21 \pm 0.04$ & $0.09 \pm 0.01$ & $0.12 \pm 0.03$ & $0.05 \pm 0.01$ & $0.05 \pm 0.01$ & n.d. & $0.09 \pm 0.03$ & n.d. & $0.09 \pm 0.03$ \\
\hline 4 & $0.14 \pm 0.02$ & $0.14 \pm 0.02$ & n.d. & $0.05 \pm 0.03$ & n.d. & $0.05 \pm 0.03$ & $0.13 \pm 0.09$ & n.d. & $0.13 \pm 0.09$ \\
\hline 5 & $0.31 \pm 0.05$ & n.d. & $0.31 \pm 0.05$ & $0.05 \pm 0.02$ & n.d. & $0.05 \pm 0.02$ & $0.14 \pm 0.04$ & n.d. & $0.14 \pm 0.04$ \\
\hline 6 & $0.20 \pm 0.03$ & n.d. & $0.20 \pm 0.03$ & $0.05 \pm 0.01$ & n.d. & $0.05 \pm 0.01$ & $0.19 \pm 0.05$ & $0.04 \pm 0.01$ & $0.15 \pm 0.04$ \\
\hline 7 & $0.11 \pm 0.02$ & n.d. & $0.11 \pm 0.02$ & $0.06 \pm 0.01$ & n.d. & $0.06 \pm 0.03$ & $0.18 \pm 0.03$ & n.d. & $0.18 \pm 0.03$ \\
\hline 8 & $0.23 \pm 0.05$ & $0.23 \pm 0.08$ & n.d. & $0.04 \pm 0.01$ & n.d. & $0.04 \pm 0.01$ & $0.16 \pm 0.01$ & n.d. & $0.16 \pm 0.01$ \\
\hline 9 & $0.11 \pm 0.03$ & n.d. & $0.11 \pm 0.03$ & $0.05 \pm 0.01$ & n.d. & $0.05 \pm 0.01$ & $0.14 \pm 0.03$ & n.d. & $0.14 \pm 0.03$ \\
\hline 10 & $0.10 \pm 0.04$ & $0.10 \pm 0.04$ & n.d. & $0.06 \pm 0.02$ & n.d. & $0.06 \pm 0.02$ & $0.21 \pm 0.10$ & $0.03 \pm 0.01$ & $0.18 \pm 0.09$ \\
\hline 11 & $0.10 \pm 0.02$ & $0.10 \pm 0.02$ & n.d. & $0.05 \pm 0.01$ & n.d. & $0.05 \pm 0.01$ & $0.11 \pm 0.05$ & $0.04 \pm 0.01$ & $0.07 \pm 0.04$ \\
\hline UNEP $(\mu \mathrm{g} / \mathrm{l})$ & 0.3 & & & 10 & & & 17 & & \\
\hline
\end{tabular}

Note: EQT $=$ UNEP Recommended Ecological Quality Targets for WIO Region (2009). Detection limits for elements in ICP-OES $\left(\mathrm{mg} \cdot \mathrm{kg}^{-1}\right) \mathrm{Hg}=0.007, \mathrm{Cr}=$ 0.002 and $\mathrm{Zn}=0.0006$. 
Dissolved zinc in water samples was detected at only five stations out of eleven. The concentration ranged from 0.01 to $0.03 \mu \mathrm{g} / \mathrm{l}$ (Table 3). Among the stations, it was found that Mtwara Port Area (station 6) and Ruvuma River Estuary (station 11) had the highest dissolved $\mathrm{Zn}(0.03 \pm 0.00 \mu \mathrm{g} / \mathrm{l})$ in the water samples. Quite unexpectedly, the Msimbazi River Estuary had no detectable dissolved zinc.

Particulate zinc was detected in the water samples from all stations ranging from $0.02 \mu \mathrm{g} / \mathrm{l}$ to $0.18 \mathrm{ng} / \mathrm{l}$. The concentration of particulate $\mathrm{Zn}$ was higher $(0.18$ $\pm 0.03 \mu \mathrm{g} / \mathrm{l})$ in the water from Mzinga Creek and also in the water sample from Mtwara Port Area $(0.18 \pm 0.04 \mu \mathrm{g} / \mathrm{l})$, while the lowest concentration $(0.02 \pm 0.01$ $\mu \mathrm{g} / \mathrm{l})$ was in the water samples from Tanga Port Area (Table 3).

\subsection{Metals Concentration in Sediments}

\subsubsection{Speciation of Arsenic in the Sediment}

The concentration of As in the sediment phases showed that about $43 \%$ of the metal was present in the geochemically available fractions of the sediments (Figure 4). The highest concentration of geochemically available fractions of As $(0.34 \pm 0.09 \mu \mathrm{g} / \mathrm{g})$ from samples collected from Msimbazi River Estuary was associated with the easily reducible fraction $\left(\mathrm{F}_{2}\right)$. The lowest amount of geochemically available As $(0.022 \pm 0.01 \mu \mathrm{g} / \mathrm{g})$ was found in samples from Mtwara Port Area only in the oxidizable fraction. The amount of As in the residual fraction $\left(\mathrm{F}_{4}\right)$ was more than $80 \%$ in the samples from estuaries of Wami, Matandu and Ruvuma Rivers.

The concentration of the total arsenic (Table 8) correlated well with Clay/Silt content of the sediment and the sediment organic matter content. Arsenic concentration in sediment samples, was within the recommended value of $7.24 \mu \mathrm{g} / \mathrm{g}$ in comparison with the maximum concentration sediment quality guideline value by UNEP [12].

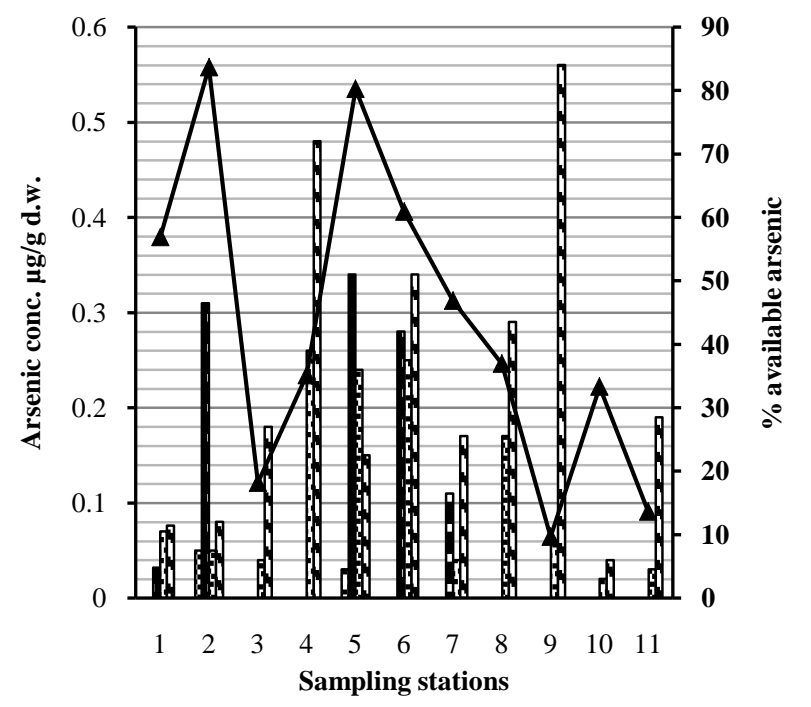

ENF1

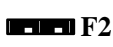

F3

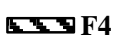

$\longrightarrow$ \% Avail. As

Figure 4. The concentration of as in sediment fractions and the percentage amount of the geochemically available arsenic. 
Table 8. Correlation coefficients (Pearson's) of the total concentrations of metals in sediments with TOM and \% clay of the sediment.

\begin{tabular}{cccccccc}
\hline & TOM (\%) & \% Clay & Total As & Total Hg & Total Cr & Total Pb & Total Zn \\
\hline TOM (\%) & 1 & & & & & & \\
\% Clay & -0.419 & 1 & & & & & \\
Total As & 0.423 & 0.454 & 1 & & & & \\
Total Hg & 0.215 & 0.266 & $0.906^{* *}$ & 1 & & & \\
Total Cr & 0.097 & 0.183 & 0.403 & 0.578 & 1 & & \\
Total Pb & 0.313 & 0.299 & 0.353 & 0.492 & 0.335 & 1 & \\
Total Zn & 0.097 & 0.142 & $0.637^{*}$ & $0.699^{*}$ & 0.540 & 0.518 & 1 \\
\hline
\end{tabular}

${ }^{*}$ Correlation is significant at the $\mathrm{p}=0.051$ ( 2 -tailed). ${ }^{*}$ Correlation is significant at the $\mathrm{p}=0.01$ (2-tailed).

\subsubsection{Speciation of Mercury in the Sediments}

Higher concentrations of $\mathrm{Hg}(56 \%)$ were present in the geochemically available fractions (Figure 5). The highest amount of the geochemically available $\mathrm{Hg}(0.05$ $\pm 0.02 \mu \mathrm{g} / \mathrm{g}$ ) was found in the sediments from the Dar es Salaam Port Area of CCMA, most of it $(78 \%)$ in the oxidizable phase $\left(\mathrm{F}_{3}\right)$. The lowest amount of the geochemically available mercury (below $0.01 \mu \mathrm{g} / \mathrm{g}$ ) was found in samples from Wami River Estuary and Mzinga Creek in the acid soluble fraction $\left(\mathrm{F}_{1}\right)$ and easily reducible fraction $\left(\mathrm{F}_{2}\right)$ respectively. Mercury at most stations was found in the acid soluble fraction $\left(\mathrm{F}_{1}\right)$ averaging $6.6 \%$. Generally, oxidizable fraction $\left(\mathrm{F}_{3}\right)$ had predominantly higher $\mathrm{Hg}$ concentrations $(>40 \%)$ than the rest of the sediment fractions (Figure 5).

Total mercury concentration in the sediment correlated well with Clay/Silt content and the organic matter content of the sediments (Table 8). Comparing with the maximum concentration sediment quality guideline value by UNEP [12], the concentration of $\mathrm{Hg}$ in the coastal marine areas of Tanzania was below the recommended value of $0.13 \mu \mathrm{g} / \mathrm{g}$.

\subsubsection{Speciation of Chromium in the Sediment}

The concentration of $\mathrm{Cr}$ in sediment fractions showed that higher amount of $\mathrm{Cr}$ $(>70 \%)$ was present in the geochemically available fractions of the sediments except at station 2 where it was 63\% (Figure 6). A large proportion of $\mathrm{Cr}$ (66\%), in the geochemically available fractions was associated with the organic and sulphur compounds in the oxidizable fraction $\left(\mathrm{F}_{3}\right)$ of the sediment. Mzinga Creek (station 7) sediments had the highest amount (90\%) of geochemically available Cr most of it (66\%) was present in the oxidizable fraction. The Pangani River Estuary which had the lowest amount of available $\mathrm{Cr}$ also had most of it (>80\%) in the oxidizable fraction (Figure 6).

There was correlation between total concentration of $\mathrm{Cr}$ in sediment with Clay/Silt content and the organic matter content of the sediments (Table 8). In comparison with the maximum concentration sediment quality guideline value by UNEP [12], the concentration of $\mathrm{Cr}$ in the coastal marine areas of Tanzania is lower than the recommended value of $53.3 \mu \mathrm{g} / \mathrm{g}$ (Table 6). 


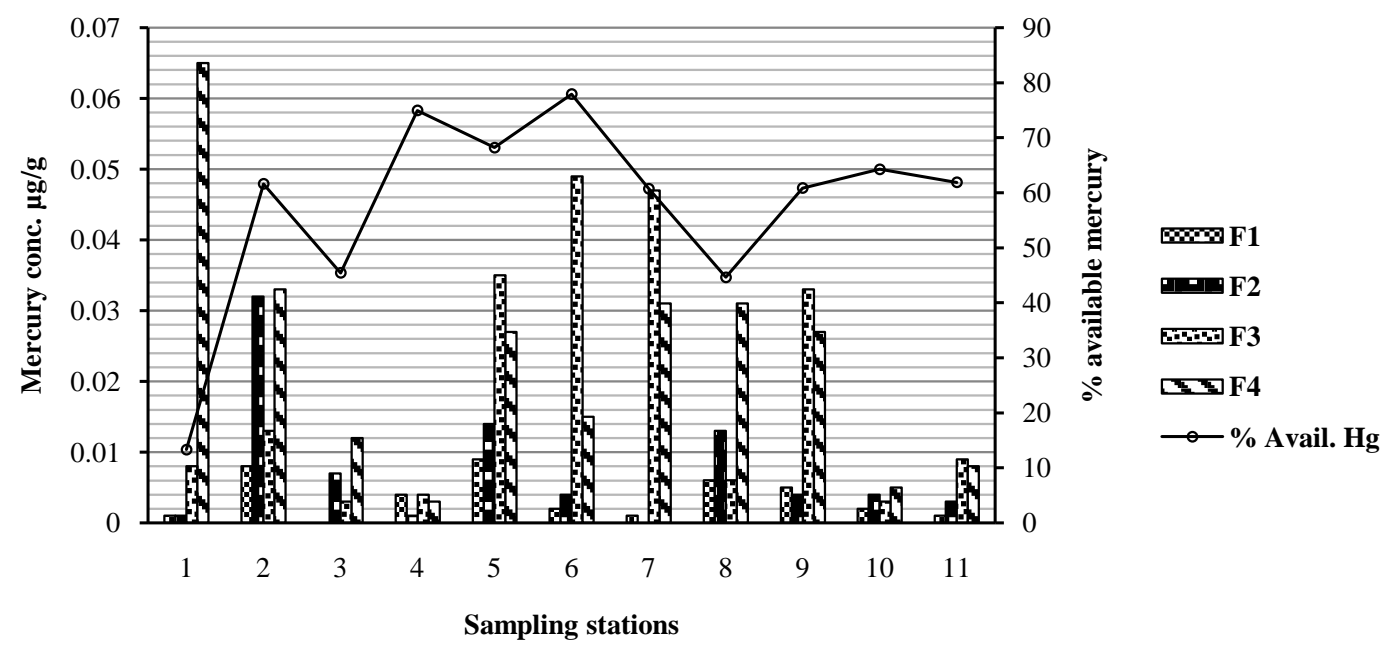

Figure 5. The concentration of $\mathrm{Hg}$ in sediment fractions and the percentage amount of the geochemically available mercury.

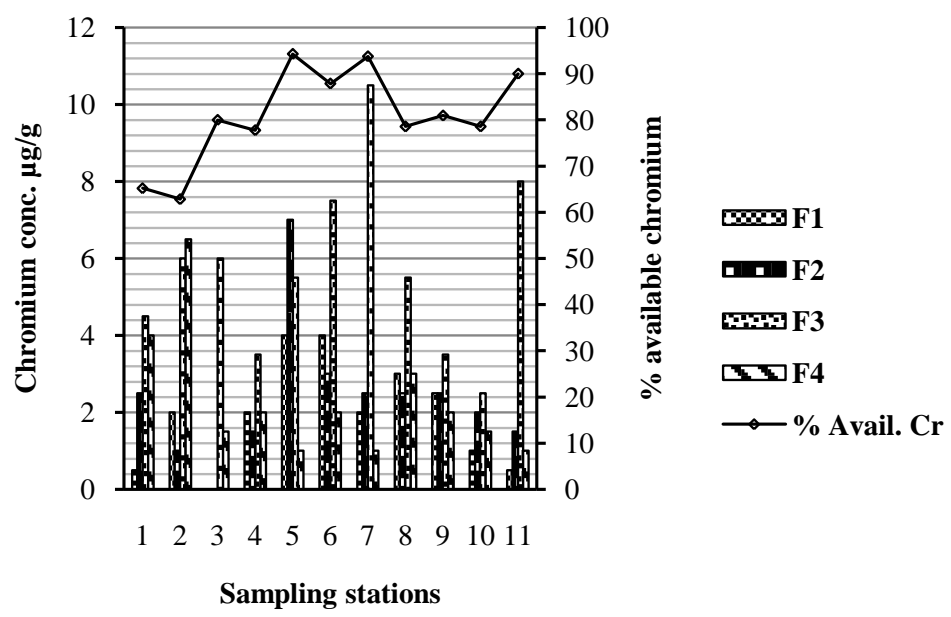

Figure 6. The concentration of $\mathrm{Cr}$ in sediment fractions and the percentage amount of the geochemically available chromium.

\subsubsection{Speciation of Lead in the Sediment}

Lead concentration in the sediment phases showed that higher amount (72\%) was associated with the geochemically available fractions of the sediment. For instance, the highest concentration of $\mathrm{Pb}(8.5 \pm 2.09 \mu \mathrm{g} / \mathrm{g})$ in the geochemically available fraction in the samples from Mzinga Creek was associated with the Fe and Mn hydrous oxides in the easily reducible fraction. The lowest amount of the geochemically available $\mathrm{Pb}(4.0 \pm 1.07 \mu \mathrm{g} / \mathrm{g})$ was found in the sediment samples from Ruvuma River Estuary, 63\% of which was associated with the Fe and Mn hydrous oxides in the easily reduced fraction (Figure 7).

Total concentration of $\mathrm{Pb}$ in sediment showed correlation with Clay/Silt content and the organic matter content of the sediments (Table 8). Total concentration of $\mathrm{Pb}$ in sediment samples from the coastal marine areas of Tanzania was low compared to the maximum sediment quality guideline value of $30.2 \mu \mathrm{g} / \mathrm{g}$ by UNEP [12]. 


\subsubsection{Speciation of Zinc in the Sediment}

The distribution pattern of $\mathrm{Zn}$ in the sediment as illustrated in Figure 8 shows that higher percentages (62\%) was present in the geochemically available fractions of the sediments. For instance, the highest concentration of $\mathrm{Zn}(69.7 \pm$ $26.14 \mu \mathrm{g} / \mathrm{g}$ ) in the geochemically available fraction was associated with the oxidizable fraction $\left(\mathrm{F}_{3}\right)$ of the samples collected from Rufiji River Estuary. The lowest amount of the available $\mathrm{Zn}(65.1 \pm 00 \mu \mathrm{g} / \mathrm{g})$ was found in the sediment samples from Tanga Port Area, where about $46 \%$ was associated with the oxidizable fraction.

The total concentration of $\mathrm{Zn}$ in sediment correlated well with Clay/Silt and the organic matter contents of the sediment (Table 8). Despite the high values, the concentration of $\mathrm{Zn}$ in the sediments of the coastal marine areas of Tanzania was lower than the maximum value of $124.0 \mu \mathrm{g} / \mathrm{g}$ by UNEP [12].

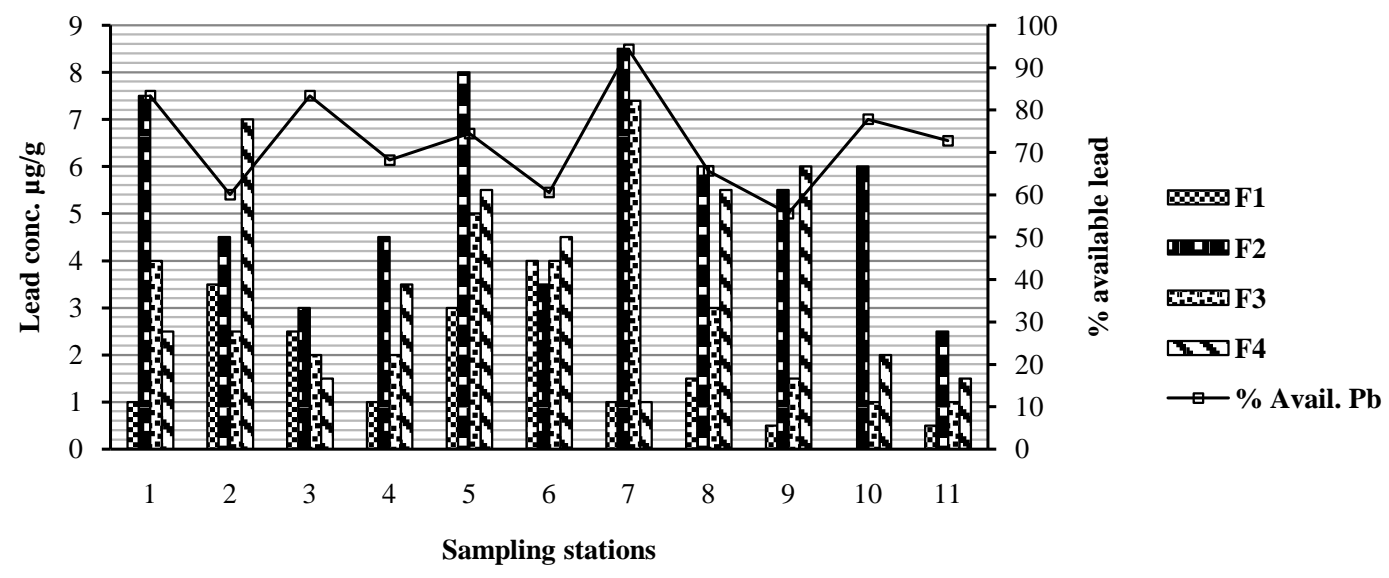

Figure 7. The concentration of $\mathrm{Pb}$ in sediment fractions and the percentage amount of the geochemically available lead.

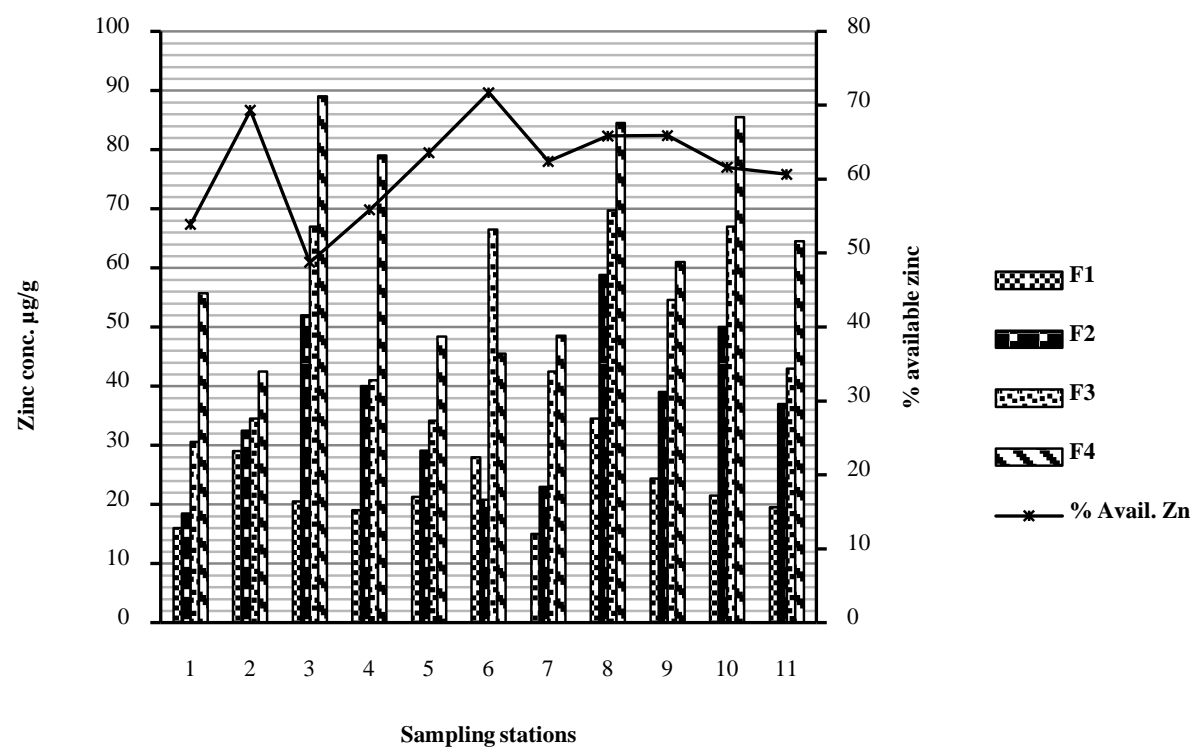

Figure 8. The concentration of $\mathrm{Zn}$ in sediment fractions and the percentage amount of the geochemically available zinc. 


\subsection{The Relationships and Enrichment Factors of the Metals in the Sediment}

The relationships between heavy metals concentrations within and between sampling locations were further investigated. Linear correlations between some metal pairs (for example $\mathrm{As}-\mathrm{Hg}$ and $\mathrm{Cr}-\mathrm{Pb}$ ) revealed excellent significant positive correlation (Table 9).

Table 10 provides the Principal Component loading where the first component comprises As and Hg (PC1) with high loadings (13.3 and 11.7). This association strongly suggests that these variables have a strong interrelationship. The second component (PC2) contributes $\mathrm{Cr}$ and $\mathrm{Pb}$ which also infers the strong correlation between this metal pair $(-1.29$ and -1.65$)$. Table 10 shows the Principal Component where the variables in the table correlated with two principal components and $\mathrm{As}-\mathrm{Hg}$ and $\mathrm{Cr}-\mathrm{Pb}$ pair can be observed to be interrelated but $\mathrm{Zn}$ showed no correlation with any analysed metals.

Enrichment factors for $\mathrm{As}, \mathrm{Hg}, \mathrm{Cr}, \mathrm{Pb}$, and $\mathrm{Zn}$ in sediment samples are presented in Figure 9. The results showed that enrichment of $\mathrm{Cr}$ and $\mathrm{Pb}$ is manifest at varying magnitude in the sediments from some sampling stations (EF greater than 2).

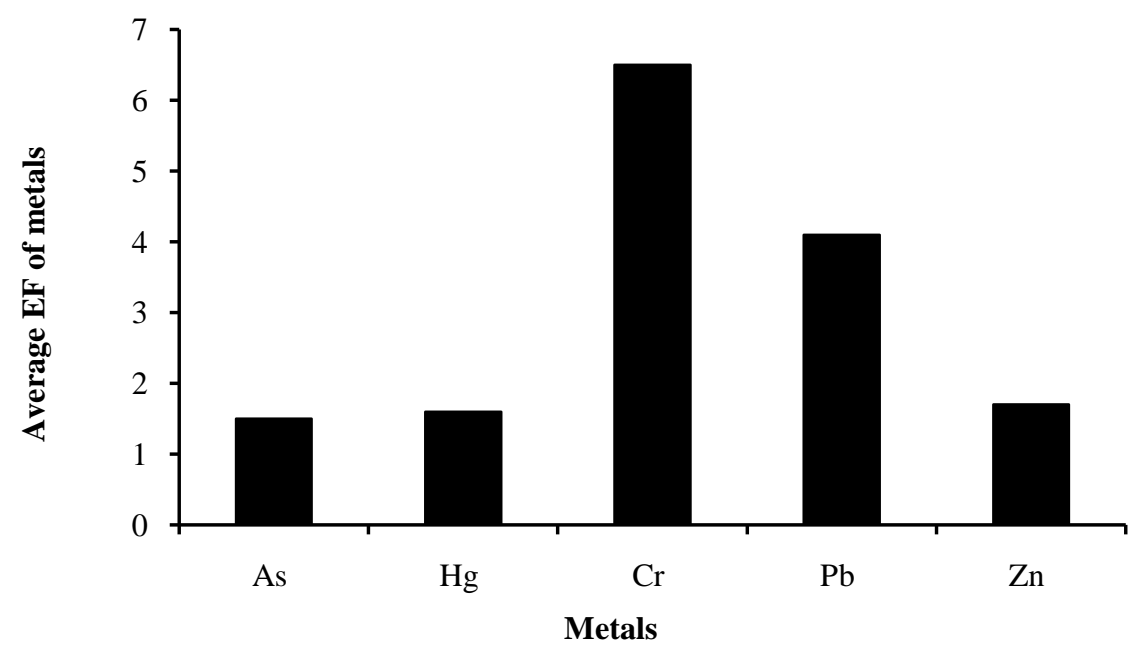

Figure 9. Average Enrichment Factors (EF) for metals in sediments.

Table 9. Correlation coefficients (Spearman's) of the total concentrations of metals in sediments.

\begin{tabular}{cccccc}
\hline & As & $\mathrm{Hg}$ & $\mathrm{Cr}$ & $\mathrm{Pb}$ & $\mathrm{Zn}$ \\
\hline $\mathrm{As}$ & 1.000 & & & & \\
$\mathrm{Hg}$ & $0.838^{* *}$ & 1.000 & & & \\
$\mathrm{Cr}$ & 0.519 & 0.355 & 1.000 & & \\
$\mathrm{~Pb}$ & 0.598 & 0.233 & $0.855^{* *}$ & 1.000 & \\
$\mathrm{Zn}$ & -0.221 & $-0.632^{*}$ & -0.576 & -0.472 & 1.000 \\
\hline
\end{tabular}

* Correlation is significant at the $\mathrm{p}=0.051$ (2-tailed). ${ }^{*}$ Correlation is significant at the $\mathrm{p}=0.01$ (2-tailed). 
Table 10. Principal component scores of metals.

\begin{tabular}{cccccc}
\hline Elements & As & Hg & Cr & $\mathrm{Pb}$ & $\mathrm{Zn}$ \\
\hline PC1 & 13.3 & 11.7 & 2.62 & 2.01 & -29.7 \\
PC2 & 1.43 & 0.779 & -1.29 & -1.65 & 0.726 \\
\hline
\end{tabular}

\section{Discussion}

\subsection{Occurrence and Speciation of Metals in Water}

The results show that about $83 \%$ of $\mathrm{Hg}$, $98 \%$ of $\mathrm{Cr}$ and $93 \%$ of $\mathrm{Zn}$ were associated with the suspended particulate matter in the sea water. This observation suggests that these metals were present in colloidal materials such as Iron and Manganese oxides or adsorbed onto organic particles including planktons. The concentration of $\mathrm{Hg}$ and $\mathrm{Cr}$ in the water were highest in the samples from CCMA followed by NCMA and lastly SCMA. Sediment samples from SCMA had higher concentration of $\mathrm{Zn}$ followed by CCMA and lastly NCMA. This is because the three sampling stations within CCMA are in Dar es Salaam City. The City has highest population density and it is the most industrial populated in Tanzania followed by NCMA and lastly SCMA. The main pollution sources which can be found around many estuaries and port areas in Tanzania includes; industrial discharges. e.g. local leather tanning which introduce $\mathrm{Cr}$, textile industries puts heavy metals and organics and also chemical industries which also adds heavy metals and organics. Other sources include urban sewage treatment plant effluents (e.g. at Dar es Salaam Port Area) which are responsible for similar pollutants loading. These results are in agreement with the previous results (which measure only total heavy metal fraction of the water), which showed that water of Dar es Salaam port area, Mzinga creek and Msimbazi river estuary in the City of Dar es Salaam contains heavy metals [13] [14] [15].

The occurrence of high particulate $\mathrm{Hg}$ at Msimbazi River Estuary suggests that the metal is mobilised by the runoff from the Dar es Salaam City. The highest concentration of particulate $\mathrm{Cr}$ was found in the water samples from Mzinga Creek (station 7) and Mtwara Port Area (station 10). Chromium in Mzinga Creek water may be resulting from discharge of dyes and colours containing chromium from the textile factory (Karibu Textile Mill) in the catchment. Also there is an abattoir; the cattle hides are initially treated in adjacent areas. The highest concentration of dissolved $\mathrm{Zn}$ observed in the water samples from Dar es Salaam Port Area suggests the source to be the nearby metal works at the port area as well as waste water and sewage discharges from unidentified sources. Higher concentration particulate $\mathrm{Zn}$ in the water from Mzinga Creek (station 7), suggests industrial-related effluent source from the textile factory. There is also an abandoned solid waste dump site at the Kizinga River catchment very close to the ocean from which seepage of the metal to the coastal area is possible. However, this observation needs further verification. The occurrence of $\mathrm{Zn}$ at Pangani River Estuary (station 2), may suggest ferry, waste from Pangani Town and 
other metal works in the area as sources. There is indication of significant mobilization of $\mathrm{Zn}$ from the catchment due to land clearance for agriculture in Pangani Estuary, which adds to its uptake and accumulation in the tissues of organisms.

\subsection{Speciation of Metals in the Sediment}

\subsubsection{Arsenic}

A high proportion ( $51 \%-94 \%)$ of As was associated with the residual fraction of the sediment possibly in association with the alumino-silicate minerals. The heavy metal fraction which is bound in the crystalline lattice of minerals is unlikely to be released in pore water through geochemical processes. Less than $25 \%$ of Arsenic was found in oxidizable fractions $\left(\mathrm{F}_{3}\right)$ in sediments from all three main sites. Small amount of arsenic was also found in the acid soluble fraction at Pangani River Estuary (11\%) and at Msimbazi River Estuary (7\%), indicating less mobility of As at those stations. Comparatively high concentration of As was also found in reduced phase at Pangani River Estuary $(0.031 \pm 0.13 \mu \mathrm{g} / \mathrm{g})$, which may be attributed to the anthropogenic inputs such as corroded ferry boats at Pangani ferry, and dumping of electronics from the local dumps along the river basin. The concentration at Msimbazi River Estuary $(0.034 \pm 0.11 \mu \mathrm{g} / \mathrm{g})$, may be attributed to the anthropogenic inputs such as run-off from the corroded Selander bridge and the municipal wastes. While the concentration at Dar es Salaam Port Area $(0.028 \pm 0.54 \mu \mathrm{g} / \mathrm{g})$, suggests anthropogenic sources such as corroded boats at DSM Port and from the municipal wastes. The difference in As concentrations between Msimbazi River Estuary and Dar es Salaam Port Area, may be due to the role played by the Msimbazi river waters which carries pollutants load from industrial run-off. The study revealed that $25 \%$ of As was present in oxidizable fraction $\left(\mathrm{F}_{3}\right)$ bound to the organic matter and sulfides. Arsenic was found to be positively correlated with total organic matter content of the sediments which attributed to the presence of smaller contents in the available phase. In oxidizable fraction As can be taken up by sediment consuming biota or filter feeders animals and incorporate in their food chains. The metals in this fraction may be released into environment if conditions become more oxidising [16]. The concentrations of As observed in this study are much lower than the As concentrations observed in other areas of the world [16].

\subsubsection{Mercury}

The distribution pattern of $\mathrm{Hg}$ illustrated in Figure 5 shows that highest $\mathrm{Hg}$ concentrations was present in the oxidizable fraction $\left(\mathrm{F}_{3}\right)$ which accounted for more than $40 \%$ of the total concentration of metal at most of the sampling stations. On the other hand, less than $40 \%$ of the total $\mathrm{Hg}$ concentration was in the residual fraction. The low percentages of $\mathrm{Hg}$ in the acid soluble fractions were associates with carbonated and oxides at Pangani River Estuary (9\%), Msimbazi River Estuary (10\%) and Rufiji River Estuary (7\%) suggesting minimum remobilization of the metal through diagenetic process in the sediment. According to 
Forstner et al. [17] a high proportion of metals in the acid soluble fraction could be regarded as a pollution indicator. Due to the low concentration of $\mathrm{Hg}$ in the acid soluble fraction, it may be considered that at the moment there is no significant threat of $\mathrm{Hg}$ poisoning in the coastal marine areas of Tanzania. Further, the occurrence of $13 \%$ of $\mathrm{Hg}$ in the easily reducible fraction in association with $\mathrm{Fe}$ and $\mathrm{Mn}$ hydrated oxides and the presence of $35 \%$ of total $\mathrm{Hg}$ in the oxidizable phase associated with organic matter and sulfides signals the importance of taking precautionary measures to establish a long term pollution monitoring program in the entire coastal water of Tanzania.

\subsubsection{Chromium}

The partitioning of $\mathrm{Cr}$ in sediments as illustrated in Figure 6 shows that more than $45 \%$ of $\mathrm{Cr}$ was found in the oxidizable fraction associated with organic and sulphur compounds. The high proportion of $\mathrm{Cr}$ in the sediments which is associated with organic matter makes the metal less available to the aquatic biota [18]. The occurrence of $32 \%$ of $\mathrm{Cr}$ in the acid soluble fraction of sediment from Pangani and Msimbazi River Estuaries and Dar es Salaam Port Area can be regarded as a high potential source of contamination to marine biota.

\subsubsection{Lead}

The distribution pattern of $\mathrm{Pb}$ in sediment as illustrated in Figure 7 shows that $38 \%$ of the total $\mathrm{Pb}$ in the three sites NCMA, CCMA and SCMA was present in the easily reducible phase associated with $\mathrm{Fe}$ and $\mathrm{Mn}$ oxides probably as a result of co-precipitation [19] [20]. The amount of lead which is extracted from the most mobile acid soluble phase $\left(\mathrm{F}_{1}\right)$ in sediments from the three main sites accounted for an average of $12 \%$. Higher percentages of $\mathrm{Pb}$ in $\mathrm{F}_{1}$ were recorded in Msimbazi River Estuary and Dar es Salaam Port Area (22\% and 29\% respectively). The higher proportion ( $>75 \%)$ of the potentially mobile $\mathrm{Pb}$ in these areas suggests precautionary measures to be taken to reduce $\mathrm{Pb}$ inputs in the coastal marine areas of Tanzania.

\subsubsection{Zinc}

In this study, $14 \%$ of $\mathrm{Zn}$ was recovered in the acid soluble fraction making the most mobile element compared to others. Relatively higher proportions of available $\mathrm{Zn}$ in the exchangeable fractions in the sediment were recorded at Rufiji River Estuary (34\%), Pangani River Estuary (29\%), Matandu River Estuary (24\%) and Msimbazi River Estuary (21\%), suggesting high potential of uptake by estuarine organisms. About $29 \%$ of the total $\mathrm{Zn}$ was in oxidizable phase $\left(\mathrm{F}_{3}\right)$ and $36 \%$ was found in the residual phase $\left(\mathrm{F}_{4}\right)$. Zinc in oxidizable phase was found in higher concentrations in the sediments from Wami River Estuary $(67 \pm 0.21 \mu \mathrm{g} / \mathrm{g})$, Dar es Salaam Port Area $(66.5 \pm 0.10 \mu \mathrm{g} / \mathrm{g})$, Rufiji River Estuary $(69 \pm 0.14 \mu \mathrm{g} / \mathrm{g})$ and Mtwara Port Area $(67 \pm 0.02 \mu \mathrm{g} / \mathrm{g})$, due to the high percentages of fine sediment (Clay/silt\%) and high organic matter content of the sediment. Similar results from other studies [3] [21] which shows high percentages of total $\mathrm{Zn}$ associated with more labile fractions in the sediments have suggested sources from anth- 
ropogenic inputs. On the other hand our results revealed that more than $50 \%$ of $\mathrm{Zn}$ in sediments from all sampling stations was present in the labile fraction which may suggest a source from anthropogenic inputs.

\section{Conclusion}

Significant concentrations of $\mathrm{Hg}, \mathrm{Cr}$ and $\mathrm{Zn}$ were found in the water and $\mathrm{As}, \mathrm{Hg}$, $\mathrm{Cr}, \mathrm{Pb}$ and $\mathrm{Zn}$ in sediments collected along marine coastal areas of Tanzania, although the concentrations were generally lower than recommended sediment quality guideline by WIOMSA. This suggests that metals studied can cause no harm to the Tanzanian aquatic biota so far. Nevertheless, regular monitoring of heavy metal levels in biota from those areas is necessary, because the results revealed the presence of a small proportion of metals associated with the geochemically available fractions of sediments which could be accumulated by aquatic biota.

\section{Conflicts of Interest}

The authors declare no conflicts of interest regarding the publication of this paper.

\section{References}

[1] Florence, T.M. (1986) Electrochemical Approaches to Trace Element Speciation in Waters. Analyst, 111, 489. https://doi.org/10.1039/an9861100489

[2] Lopez-Sanchez, J.F., Rubio, R., Samitier, C. and Rauret, G. (1996) Trace Metal Partitioning in Marine Sediments and Sludge Deposited off the Coast of Barcelona (Spain). Water Research, 30, 153-159. https://doi.org/10.1016/0043-1354(95)00129-9

[3] Kozelka, P.B. and Bruland, K. (1998) Chemical Speciation of Dissolved Cu, Zn, Cd, $\mathrm{Pb}$ in Narragansett Bay, Rhode Island. Marine Chemistry, 60, 267-282. https://doi.org/10.1016/S0304-4203(97)00107-2

[4] Florence, T.M. (1982) The Speciation of Trace Element in Waters. Talanta, 29, 345364. https://doi.org/10.1016/0039-9140(82)80169-0

[5] Kersten, M. and Forstner, U. (1991) Speciation of Trace Elements in Sediments. In: Batley, G.E., Ed., Trace Element Speciation: Analytical Methods and Problems, CRC Press, Boca Raton, 245-317.

[6] Waldichuk, M. (1985) Biological Availability of Metals to Marine Organisms. Marine Pollution Bulletin, 16, 7-11. https://doi.org/10.1016/0025-326X(85)90252-8

[7] Ure, A.M., Quevauviller, Ph., Muntau, H. and Griepink, B. (1993) Speciation of Heavy Metals in Solids and Harmonization of Extraction Techniques Undertaken under the Auspices of the BCR of the Commission of the European Communities. International Journal of Environmental Analytical Chemistry, 51, 135. https://doi.org/10.1080/03067319308027619

[8] Schwarz, K. (1977) Essentiality versus Toxicity of Metals. In: Brown, S.S., Ed., Clinical Chemistry and Chemical Toxicology of Metals, Elsevier/North Holland, Amsterdam, 3-22.

[9] Dinu, C., Vasile, G. and Popescu, L.R. (2011) Determination of Volatile Metallic Elements in Water Using Flow Injection Hydride Generation Coupled with FIASICP-OES. INCD ECOIND_International Symposium SIMI 2011 “The Environment 
and the Industry", Vol. 2, 147-154.

[10] Nelson, D.W. and Sommers, L.E. (1996) Total Carbon, Organic Carbon, and Organic Matter. In: Page, A.L., et al., Eds., Methods of Soil Analysis, Part 2, 2nd Edition, Agronomy No. 9, American Society of Agronomy Inc., Madison, 961-1010. https://doi.org/10.2136/sssabookser5.3.c34

[11] Yuan, C., Shi, J., He, B., Liu, J., Liang, L. and Jiang, G. (2004) Speciation of Heavy Metals in Marine Sediments from the East China Sea by ICP-MS with Sequential Extraction. Environment International, 30, 769-783. https://doi.org/10.1016/j.envint.2004.01.001

[12] NEP/NCS and CSIR (2009) Guidelines for the Establishment of Environmental Quality Objectives and Targets in the Coastal Zone of the Western Indian Ocean (WIO) Region. UNEP, Nairobi, 175 p.

[13] Machiwa, J.F. (1992) Heavy Metal Content in Coastal Sediments of Dar es Salaam, Tanzania. Environment International, 18, 409-415. https://doi.org/10.1016/0160-4120(92)90073-D

[14] Bungala, S.O. (2002) Physico-Chemical Characteristics of Heavy Metal Pollutants in River Yombo, Mzinga and Kizinga in Dar es Salaam. MSc. Thesis, University of Dar es Salaam, Dar es Salaam.

[15] Kruitwagen, G., Hecht, T., Pratap, H.B. and Wendelaar Bonga, S.E. (2006) Changes in Morphology and Growth of the Mudskipper (Periophthalmus argentilineatus) Associated with Coastal Pollution. Marine Biology, 149, 201-211. https://doi.org/10.1007/s00227-005-0178-Z

[16] Meharg, A.A. and Hartley-Whitaker, J. (2002) Arsenic Uptake and Metabolism in Arsenic Resistant and Nonresistant Plant Species. New Phytologist, 154, 29-43. https://doi.org/10.1046/j.1469-8137.2002.00363.x

[17] Forstner, U. and Wittmann, G.T. (1981) Metal Pollution in Aquatic Environment. 2nd Edition, Springer-Verlag, Berlin, 486.

https://doi.org/10.1007/978-3-642-69385-4

[18] Usero, J., Gamero, M., Morillo, J. and Gracia, I. (1998) Comparative Study of Three Sequential Extraction Procedures for Metals in Marine Sediments. Environment International, 24, 487-496. https://doi.org/10.1016/S0160-4120(98)00028-2

[19] Fernandez, C.J.C., Munoz, F.R. and Galan, E. (1997) Clay Mineral and Heavy Metal Distributions in the Lower Estuary of Huelva and Adjacent Atlantic Shelf, SW Spain. Science of the Total Environment, 198, 181-200. https://doi.org/10.1016/S0048-9697(97)05450-8

[20] Lee, B.-G., Griscom, S.B., Lee, J.-S., Choi, H.J., Koh, C.-H., Luoma, S.N. and Fisher, N.S. (2000) Influences of Dietary Uptake and Reactive Sulfides on Metal Bioavailability from Aquatic Sediments. Science, 287, 282-284. https://doi.org/10.1126/science.287.5451.282

[21] Zhou, Y.-W., Zhao, B., Peng, Y.-S. and Chen, G.-Z. (2010) Influence of Mangrove Reforestation on Heavy Metal Accumulation and Speciation in Intertidal Sediments. Marine Pollution Bulletin, 60, 1319-1324.

https://doi.org/10.1016/j.marpolbul.2010.03.010 